\title{
perifèria
}

Número 19 (1), Juny 2014

revistes.uab.cat/periferia

\section{A "libertação de demônios" como cotidianidade: esboço de um estudo etnográfico}

\author{
Ypuan Garcia - Universidade de São Paulo ${ }^{1}$
}

\begin{abstract}
Resumo
O objeto deste artigo é o conceito nativo de "libertação de demônios", tal como se articula em um grupo de católicos renovados da Região Oeste da cidade de São Paulo, no Brasil. Seu propósito é apresentar uma primeira análise da "libertação" como cotidianidade, argumentando que as noções nativas de "abertura", "caminhada" e "Verdade" são centrais para o entendimento das formas pelas quais se evita, diariamente, a cativação por seres malignos. Inicio de uma abordagem teórica baseada na etnografia e exponho, em seguida, que a ausência de uma reflexão sobre a cotidianidade dos encontros com o mal pode levar à sobreinterpretação na análise acerca da "libertação".
\end{abstract}

Palavras-chave: Libertação, Cotidianidade, Abertura, Caminhada, Verdade

\begin{abstract}
The object of this article is the native concept of "deliverance from demons" as articulated in a group of renewed Catholics in the Western Region of the city of São Paulo, Brazil. The purpose is to present an initial analysis of "deliverance" as ordinariness, arguing that native notions of "openness", "walk" and "Truth" are central to understanding the ways in which the persons daily avoid to be tempted by evil beings. I start from the theoretical approach grounded in the ethnography and then show that the absence of a reflection on the ordinariness of the encounters with the evil can lead to overinterpretation in the analysis about "deliverance".
\end{abstract}

Key words: Deliverance, Ordinariness, Openness, Walk, Truth

\footnotetext{
${ }^{1}$ Enviar correspondencia a Ypuan Garcia, bolsista da Fundação de Amparo à Pesquisa do Estado de São Paulo, no endereço eletrônico: ypuangarcia@gmail.com
} 


\section{perifèria}

Número 19 (1), Juny 2014

revistes.uab.cat/periferia

\section{Introdução:}

Este artigo se propõe a debater o argumento oriundo de uma etnografia, ainda se fazendo, segundo o qual a "libertação ${ }^{2}$ de demônios", ou "cura espiritual" (doravante, "libertação") seria diária ${ }^{3}$. O delivramento, na teoria nativa, suporia basicamente uma necessidade motivada pelas implicações para os humanos da rivalidade entre seres agentivos não-humanos, Deus e o Diabo, que estão no mundo. O mal, por isso mesmo, não seria especulado através da excepcionalidade, mas pela "cotidianidade" (Veyne 1996). Essa imagem contrapõe-se à ficção analítica que incide sobre a transcendência/sacralidade do coletivo e a imanência/profanidade do individual (Csordas 1990; Asad 1993; Bialecki 2011). Paul Veyne realça que "sobreinterpretar", ao revés da "cotidianidade", é interpretar exageradamente, tornando o exotismo um ponto de partida, uma teoria, que "(...)

\footnotetext{
2 Preferi traduzir o termo "libertação", para o leitor espanhol, inicialmente, como "librarse de", em lugar de "liberácion": "Librar (verbo transitivo): 1. (Com de) Salvar o preservar alguien de algo que se considera difícil, perjudicial o negativo: La influencia de su família ló libró de la cárcel por lo menos quince veces. (Gran Diccionario de Uso del Español Actual, 2001)". Não se perde o seu sentido geral na teoria nativa: "A libertação é o ato da pessoa ser livre. É só o nome que dá para o que acontece (...) A libertação é estar sendo liberto de algo: de um vício, de um trauma, de um demônio...". Em suma, a livrança tem a ver com a dissolução de alguma forma de cativeiro, um "desembaraçar-se de" ("desembarazarse de"). Mais adiante, veremos que a "libertação", diferentemente do "exorcismo", é menos a extração do demônio do que uma maneira de mantê-lo afastado, evitar a sua aproximação. Avizinho-me, com o desenrolar do texto, da tradução, mais do que perspicaz, que a prof ${ }^{a}$ Virginia Fons, no Congresso de Antropologia UAB-USP, em abril do ano de 2014, deu ao termo, "liberácion". Este teria a ver com a "educação da atenção" (Ingold 2001) do humano que se encontrava cativo. Agradeço à referida prof ${ }^{a}$ por ter suscitado tanto a importância de esclarecer a noção para um público não brasileiro quanto pelos inúmeros comentários. A escrita, em ampla medida, repercute sua valiosa contribuição e generosidade, embora não esteja à altura de todas as suas sugestões por causa da incipiência da análise.
}

${ }^{3}$ Apresento uma abreviação brusca dos dados etnográficos. As designações do tipo "os nativos dizem..." ou "conforme os nativos..." atendem ao esforço deliberado para o funcionamento da economia do argumento. As interpolações das falas nativas, na escrita, são abundantes. As traduções dos textos e dos termos, que, na bibliografia, constam no original, são de inteira responsabilidade minha. 


\section{perifèria}

Número 19 (1), Juny 2014

revistes.uab.cat/periferia

consiste em fabricar falsas intensidades (...) Imaginando que a intensidade é o regime de cruzeiro da cotidianidade, ofuscada pelo brilho do exótico" (Veyne 1996: 250-251).

Pretendo discutir a provável "banalidade" (Veyne, 1996) da "libertação" através dos conceitos de um "coletivo"" de "católicos não-cessacionistas", qual seja, que defende a ininterrupção da proliferação dos dons do Espírito Santo mesmo depois do "período apostólico" (Bonfim 2012: 54) . O "coletivo" com quem estive por sete meses, durante os anos de 2013 e de 2014, foi a Missão Eucarística Círculo do Pão e os seus afluentes, que são os seguintes: o grupo de oração Santíssima Trindade ${ }^{6}$, o mais antigo da região; a Paróquia de Cristo Operário, onde se realizam as "Missas de Cura e Libertação"7 e os encontros do Grupo de Adoração Eucarística Círculo do Pão. O padre João conduz ambos. Em um recanto mais afastado, no Bairro da Pedra Grande, está a Casa de Acolhimento da Missão Eucarística Círculo do Pão,

4 O conceito de "coletivo" é um empréstimo de Bruno Latour (2001) e tem como desígnio sublinhar, para além da noção de sociedade, um cosmo habitado por meio das associações entre humanos e nãohumanos.

5 Tendo em perspectiva que algumas das pessoas com quem convivo me pediram para não serem identificadas, utilizarei nomes fictícios para humanos, lugares e coletivos com o propósito de preservar aquilo que me foi solicitado.

6 A fundação do grupo remonta a vinte e cinco anos. O grupo integrou a Renovação Carismática Católica; afastou-se dela; e foi renomeado como Santíssima Trindade. A sala em que ocorrem os encontros é ornada com quadros de imagens de santos, além de uma pequena capela, protegida por portas corrediças de madeira, que é aberta para as orações individuais e para a adoração do "Santíssimo", a hóstia consagrada no ostensório. A Missão Eucarística Círculo do Pão possui quatro anos e tem aproximadamente 400 "missionários". Dezessete destes, excetuando-se os casados e os solteiros, são celibatários, isto é, fizeram votos de castidade, de pobreza e de obediência.

7 O que a distancia das missas diárias é que o "Santíssimo" é levado para a nave da Igreja. O padre é acompanhado pelo "Ministério de Música". Cantam-se louvores até que o Espírito Santo seja ativado. O sacerdote, então, começa a enumerar o que está sendo curado e o motivo dos mal-estares, ocasionados, por um demônio, um objeto consagrado (uma comida), a ida a "lugares" em que se cultuam divindades não católicas etc.. A procissão com Jesus Sacramentado é o ápice da missa, momento em que se abençoa todo o tipo de objeto. 


\section{perifèria}

Número 19 (1), Juny 2014

revistes.uab.cat/periferia

destinada a receber "irmãos de rua", sendo próxima da Casa Feminina, no mesmo bairro. A Casa Masculina, no bairro da Pedra Grande, encontra-se interposta à Casa de Acolhimento ${ }^{8}$.

\section{$* * *$}

Pretendia, inicialmente, estudar a "libertação" e me baseei no trabalho de Thomas J. Csordas (1990, 1994, 2002). A definição primeira da "libertação" era a seguinte: uma modalidade de "cura ritual" em que a existência de aflições proporcionadas por entidades malignas seria central.

O desenvolvimento da pesquisa, todavia, me levou a considerar uma mudança no sentido daquilo que designara por "cura ritual" em direção aos seus aspectos discursivos $^{9}$, em lugar de centralizar a análise de práticas e performances. 0 acento nessas condições procedeu de um tipo de dificuldade que se apresentou ao mencionar o substantivo "libertação": a maneira como se evita falar dele quando se está com alguém que "vem da universidade". Os nativos receavam que estivesse em busca do "sensacionalismo", do "show", que a acompanha, isto é, que a confundisse com o que se passa nas denominações pentecostais. A preocupação com o aspecto extravagante do mal seria, em tese, uma projeção da disciplina.

O equívoco na minha observação levou-me à invenção de um impasse que, em alguma medida, era a decorrência da minha pouca intimidade com aquelas pessoas. Fiquei paralisado pelo movimento pendular das duas maneiras de tecer uma trama persuasiva. A primeira, já mencionada, provinha das referências a Csordas (1994); a segunda remetia a algo que Edward E. Evans-Pritchard (2005)

\footnotetext{
${ }^{8}$ Os trajetos podem ser feitos a pé. A maior distância percorrida não consome uma hora.

${ }^{9}$ A noção de discurso é empregada no sentido daquilo que se diz sobre algo, sem que esse algo esteja presente. Redunda de um lugar-comum do trabalho de campo. Não é o resultado de qualquer orientação teórica. De certa maneira, evito lançar mão de um conceito que não está, por ora, no meu horizonte teórico.
} 


\section{perifèria}

Número 19 (1), Juny 2014

\section{revistes.uab.cat/periferia}

se deparara entre os Azande, devido à opacidade empírica da feitiçaria, uma vez que a excrescência seria constantemente um atributo alheio, do "outro" (FavretSaada, 1990). Ou bem me atinha às presenças (prática), ou bem me ligava às ausências (discurso). Nossa tentativa foi escapar da atração pela extravagância e da decepção pela falta dela.

O texto é subdividido em cinco tópicos, pois desfia aspectos da etnografia que trouxeram alguma especificidade para a argumentação. O primeiro é a admissão de que o aspecto movente da "libertação" precipitou a reconceptualização da "cura ritual", obrigando a fazer uma discussão sobre a ênfase dada à fenomenologia nos processos saúde-doença. O segundo descreve a atenção destinada à "libertação", em vez do "exorcismo". Em acréscimo, delimita que a "libertação" opera através de uma "abertura" para que o nativo se deixe agenciar pela divindade. O terceiro, uma expansão do segundo, aborda, de forma principiante, que a "precaução10" é o aspecto ordinário da "libertação", o que diminui a inquietação inicial da pesquisa com a performance e com o ritual. O quarto vai ao encontro do segundo, pois insiste que a "abertura" é uma forma específica de conceptualizar a "Verdade", que, segundo os nativos, é uma "pessoa". O quinto esboça que a "precaução" e a "Verdade" se juntam a um terceiro aspecto da "libertação", a "caminhada", rascunhando, em um esforço deliberado de acoplá-los, uma ideação abdutiva ${ }^{11}$ da

10 O conceito de "precaução" não trai as maneiras de "estar atento", "estar acordado" no mundo nativo. De preferência, é uma reminiscência ao Evangelho de Marcos: "Vigiai, pois, visto que não sabeis quando o senhor da casa voltará, se à tarde, se à meia-noite, se ao cantar do galo, se pela manhã, para que, vindo de repente, não vos encontre dormindo" (Marcos, 13, 35-36). Após algumas conversas, durante a pesquisa de campo, sobre a "precaução", decidi incorporá-la a um dos aspectos gerais da "libertação". A tradução indica, neste caso, uma traição mínima às ideações nativas. Essa pequena torção foi importante, pois esvaziou, no seio da própria etnografia, a importância do conceito de ritual.

${ }^{11}$ A incompletude, a parcialidade e o inacabamento da natureza humana (Sahlins, 2004) tornam, por dois motivos, uma sequência ritual da "libertação", mesmo que por um esforço deliberado, improvável entre esses cristãos. No primeiro, a pessoa, essencialmente, é fraca, além de possuir três instâncias: física, mental e espiritual. A pessoa é concebida enquanto um compósito de mente, corpo e espírito, correlatos respectivos da tripartição (Csorda, 1994) da divindade entre o Pai, o Filho e 


\section{perifèria}

Número 19 (1), Juny 2014

revistes.uab.cat/periferia

livrança - abdutiva porque admite que "(...) há relações de comunicação, de conexão que nós precisamos tentar identificar" (Velho 2007: 328).

Cabe ressaltar que este artigo não comparará reflexões distintas sobre a "libertação" no cosmo cristão brasileiro, porém suscitará, a partir de uma pesquisa em andamento, algumas implicações teóricas para a uma provável conceptualização da "libertação" como "cotidianidade".

\section{O problema da "cura ritual"}

Quando iniciei a pesquisa, a definição de "antropologia das terapias" vinculava-se ao modo que a eficácia da "cura ritual" operaria de maneira decisiva, porque concedia uma tradução à doença nos termos da relação entre humano e sagrado (Lévi-Strauss 1967; Montero 1985; Favret-Saada 1989, 1990; Desjarlais 1992; Csordas 1990, 1994, 2004). O acento era na ação transformadora da terapia sobre os estados desordenados e confusos característicos da aflição (Csordas 1990). A redução que se segue das inúmeras teorias dos processos de saúde-doença, além de empobrecer o debate, é manejada em conformidade com os interesses do texto. Por ser um recorte, é um exercício parcial. Daqui alarguei as referências, pois era fundamental situar a importância destinada ao "sujeito" no trabalho de Csordas.

o Espírito Santo. No segundo, se lançássemos mão da temporalidade baseada no ritual, nos veríamos às voltas com mais um obstáculo teórico, pois teríamos de enfrentar o kairos, o qual denota tanto um momento oportuno em que se fixa um compromisso com Deus quanto, segundo Bruno Latour, "(...) uma alteração da pulsação e do andamento da experiência (...) é a palavra que os gregos teriam empregado para designar esse sentido novo de urgência" (Latour 2004: 351). O kairos se oporia a qualquer ritualização ou transição ritualística, porque o movimento do Paracleto é imprevisível: "O Vento Santo [Espírito Santo] sopra onde quer (...)" (João, 3, 8). Em síntese, o conceito de pessoa não corresponde imediatamente ao divisor entre mente e corpo, e a moção divina não é uma ocorrência antecipável. 


\section{perifèria}

Número 19 (1), Juny 2014

revistes.uab.cat/periferia

Paulo C. Alves $(2006)^{12}$ pontua que uma das principais preocupações nos estudos sócio-antropológicos da saúde se relaciona com a emergência, na década de 1980, de pesquisas voltadas para a "experiência da doença". As análises partem do enlace metodológico entre hermenêutica e fenomenologia, um dos motores principais do "paradigma do embodiment" (Csordas, 1990). Elas criam deliberadamente um distanciamento em relação às ditas "teorias sistêmicas", elaboradas a partir da década de 1950. Exageram uma diferença para constituir outras.

Por teorias sistêmicas, considero as analogias empregadas com a pretensão de explicitar as qualidades socioculturais das enfermidades. A teoria de Talcott Parsons foi a primeira grande narrativa sobre o tema. A saúde era um "pré-requisito funcional" (Alves 2006: 1548) para a manutenção da estrutura social, ao passo que a doença precipitava uma anormalidade que deveria ser corrigida pelo sistema. Notemos que a analogia parsoniana era um empréstimo da biologia. A sociedade seria, então, um organismo e seu bom funcionamento dependeria dos papéis que enfermos e médicos adotariam com a finalidade de restaurar esse equilíbrio. Dito de outra forma, as condutas ideais do paciente e do terapeuta preexistiriam às suas relações.

A dicotomia entre disease (to cure) e illness (to heal) ${ }^{13}$ foi o produto implícito da formulação parsoniana. Ela ampliou o escopo das análises e gerou um solo fértil para a "teoria do conflito", uma ramificação da teoria sistêmica, que não

\footnotetext{
${ }^{12}$ A escolha de Alves é uma dentre das inúmeras possíveis, à medida que essas coletâneas e revisões teóricas são abundantes e funcionam como verbetes acerca do tema (ver Frankenberg, 1980; Langdon, 1994; Langdon \& Fóller, 2012).

13 Não dispomos, na língua portuguesa, de correspondências etimológicas para desobscurecer a distinções entre illness ("teoria leiga") e disease ("teoria oficial") e seus respectivos pares verbais correspondentes, to heal ("subjetivação da aflição") e to cure ("objetivação da aflição") (sobre exposições mais esquemáticas e fundacionais dessas distinções, ver Kleinman (1978); Lieban (1977); Frankenberg (1980)).
} 


\section{perifèria}

Número 19 (1), Juny 2014

\section{revistes.uab.cat/periferia}

questionava a preeminência cognitiva ${ }^{14}$ da sociedade, mas as discrepâncias pelas quais os grupos sociais lidavam com o princípio hegemônico e regulador da medicina no mundo ocidental ao revés do "sistema leigo". Em geral, a medicina continuava a ser vista como um subsistema autocorretivo da sociedade. Soma-se à "teoria do conflito", a propagação, no final da década de 1950, de pesquisas intituladas de "illness behaviour", interessadas no "comportamento do doente". Esses estudos avançaram internamente com uma divisão que introduz uma metade, complementar e inversa, "estrutural-coletivista". Esta é baseada nas variantes etárias e sociais; aquela, nas motivações individuais (Alves 2006: 1049).

A totalidade dos pressupostos supracitados agrupou-se, posteriormente, nos estudos de "representação social" da doença. A sociedade era o manancial cognitivo, um mapa, que nortearia as interpretações, a comunicação e as condutas que os sujeitos interiorizavam em consonância com o grupo a que pertenciam (Alves 2006: 1550).

Arthur Kleinman, no ínicio da década de 1980, estabeleceu a "teoria dos modelos explicativos". Supôs a tripartição dos "sistemas de cuidados à saúde" ("health care systems"): o "profissional" (biomedicina), o "folk" (a terapia religiosa) e o "popular" (leigos). O último era o principal, porque concentrava a maioria dos saberes e práticas em relação ao fenômeno saúde e doença (Alves 2006: 1550). Os "modelos explicativos" seriam comparáveis entre si, à proporção que o "saber popular" da doença era transcultural.

Embora mantenha o ato de pensar como um corolário da vida coletiva, a "teoria dos modelos explicativos" concebeu uma fresta para a construção de uma visada fenomenológica da doença por causa da valorização da "experiência da enfermidade" e da transculturalidade (Alves 2006: 1551), opondo-se à "teoria sistêmica". A guinada fenomenológica é auxiliada pela hermenêutica. O primeiro passo é considerar que a teoria representacional produzia explicações. O segundo

\footnotetext{
${ }^{14} \mathrm{Em}$ suma, não se opunha à asserção de que a natureza do pensamento é indubitavelmente social, o que atravessa a antropologia britânica, inspirada na sociologia durkheimiana, e a antropologia norteamericana, por meio das asseverações de Clifford Geertz (Ingold 2000).
} 


\section{perifèria}

Número 19 (1), Juny 2014

revistes.uab.cat/periferia

passo, baseado na hermenêutica, introduz a interpretação de interpretações, pois só o nativo tem acesso em primeira mão à sua experiência (Geertz 1989). Não surpreende que a doença tenha no "sistema cultural" um nível de complexidade mais abrangente. Cria as possibilidades de comparar transculturalmente os "sistemas de cuidados à saúde" e de opor a "subjetividade" à "objetividade" nesses sistemas (Alves 2006: 1551).

Byron J. Good - baseado em Clifford Geertz, Peter Berger e Thomas Luckman concede estatuto interpretativo à doença. A introdução da fenomenologia ${ }^{15}$ tem a ver com um novo resgate do sujeito enquanto locus de agentividade, e, desse modo, escapa da perspectiva em que a ação é a atualização da mente coletiva e não meramente uma inconstância da mente individual. Ação e experiência se equivalem e resgatam o sensível, os sentimentos ${ }^{16}$. O "mundo da vida" ("Lebenswelt"), do plano perceptivo, é uma construção humana. A especulação de que a sociedade explica a natureza das relações, ao contrário das aparências, é ampliada porque os sentimentos são do domínio da cultura, assim como as modalidades intersubjetivas do mal-estar, da aflição e da enfermidade. O desenlace disto é a manutenção da hermenêutica, uma tentativa teórica de não perder a estabilidade da significação. O modelo é o da cultura como se fosse um texto (Alves 2006: 1552; Asad 1993). A doença é uma ruptura no campo intersubjetivo, onde o "outro" é quase um "eu mesmo". Não surpreende que o "não-eu", o "totalmente outro", o demônio, (Csordas, 1990), seja, frequentemente, posicionado como uma

15 O antropólogo norte-americano A. Irving Hallowell, conforme Good (2012), foi quem elaborou uma teorização, no sentido forte, da fenomenologia cultural através de suas análises sobre o meio ambiente comportamental do self entre os Ojibwa. As descrições de Hallowell contrastavam-se, ressalva Good, com as posições racionalistas de seus contemporâneos na antropologia britânica. Clifford Geertz (1989) seguiu esse deslocamento. Tornou-se o grande proponente da tradição fenomenológica, não obstante uma sociologia fenomenológica inspirada em Alfred Schutz.

${ }^{16}$ Jack Katz e Thomas J. Csordas (2003) pontuam que a "fenomenologia cultural" surge no seio da crise da representação ou da etnografia inserida no período modernista da disciplina. Pode ser definida como "(...) a preocupação em sintetizar a imediatidade da experiência encorporada (embodied) com a multiplicidade do significado cultural em que estamos sempre e inevitavelmente imersos" (Csordas 1994: VII; grifos nossos). 


\section{perifèria}

Número 19 (1), Juny 2014

revistes.uab.cat/periferia

construção cultural para agrupar as perturbações que são supostamente o resultado de um comportamento anti-social ${ }^{17}$. A "libertação", que se refere à fração espiritual do conceito nativo de pessoa, é esvaziada.

A problematização da alteridade, da presença de um "outro", nos levou a repensar a argumentação de Csordas. Ela não avançaria porque o conceito de cultura seria relativisticamente empregado, uma vez que ele neutralizaria a perturbação advinda de algo central: demônios existem, quer se acredite neles ou não. A discussão da existência desse ser é da ordem da "Verdade"18. A limitação de Csordas pode ser delineada, uma vez que o "deslocamento" do "eu" origina-se "(...) da emoção e do comportamento intratáveis (...) como interpessoais [intersubjetivos]" (Csordas 1997: 187). Caso fosse por aí, acabaria por evocar uma narrativa analítica que suscitaria as metáforas de ausência de comunicação/relação em situações de aflição. Ficariam, assim, circunscritas à tensão entre processos internos e externos (emocionais/sociais=espirituais) dos afligidos.

Não haveria como se desviar das paralisias da explicação social (como funciona, denúncia dos verdadeiros motivos) e da interpretação cultural (versões alternativas de um mesmo mundo). As duas não ajudam a lidar com a "libertação" e possuem como eixo comum inventar um cosmo exclusivamente humano. A "retórica sociológica" colocaria o "demônio" na posição de uma "representação coletiva da pessoa como um repertório de atributos negativos" (Csordas 1994: 185). A "interpretação cultural" conduziria aos processos em que o mal é internalizado pelo indivíduo no sentido csordiano. Nas duas dimensões, atribui-se importância à construção e à criação de uma "realidade humana" (Csordas 1994: 165) para o sofrimento, codificando-o na "cura ritual".

\footnotetext{
17 A herança do argumento é durkheimiana (Durkheim 1996) e tem uma longa carreira na disciplina (Douglas 1970; Berger 1973; Geertz 1989). Ainda assim, se desdobra em monografias mais recentes e que abordam, explicitamente, a relação entre representação e emoção (Desjarlais 1993; Csordas 1994), sendo pensada menos por um divisor radical do que pela evocação de complementaridades analíticas entre semiótica e fenomenologia, por exemplo.

${ }^{18}$ Adiante, voltaremos à questão.
} 


\section{perifèria}

Número 19 (1), Juny 2014

revistes.uab.cat/periferia

Para finalizar este tópico, vale mencionar que, ao longo da pesquisa, a posição do "não-eu", do demônio, na "libertação", era de um "Ele", isto é, o ser maligno tinha a designação pronominal da terceira pessoa com quem mantém algum tipo de conexão, no mínimo, familiar. As sentenças são inúmeras: "Ele gosta da confusão"; "Ele vai tentar te seduzir"; "Ele é o pai da mentira"; "Ele te pega na sua fraqueza" etc.. O mal-estar é um momento de ampliação das relações com um mundo que "gera valor" (Velho 2001: 136).

No cosmo nativo, a raiva pode se tornar um "Espírito de Raiva/Ódio" quando é excessiva. O que caracteriza um ataque maligno não é uma insuficiência relacional, mas uma superabundância desta. Clara, uma missionária bastante requisitada por causa da unção das suas orações, em uma conversa no "grupo de oração", chega a dizer que

"(...) a raiva ruminada vira ódio. O ódio se transforma em um espírito e toma conta. A raiva é momentânea. O ódio maquina. Vê que isso acontece quando alguém mata a mulher [esposa]. A bulimia e a anorexia são um exemplo. 0 olhar maligno está ali para destruir a pessoa".

A transformação de um sentimento em um demônio não fixa a sua inexistência inicial, pois "Ele" está presente ${ }^{19}$ no dia a dia.

\footnotetext{
${ }^{19}$ A nomeação dos demônios por emoções, comportamentos e padrões negativos de pensamento tem três implicações: a primeira é o "discernimento", um dom do Espírito Santo, dos domínios humanos e não-humanos do tormento, posto que, em muitas ocasiões, como dizem os nativos: "É do psicológico da pessoa". Amplia, por conseguinte, o alcance da "libertação", pois abre a possibilidade da pessoa lançar mão da psicoterapia. Não observei, entretanto, uma relação direta entre o mal-estar e a nomeação do demônio. O "espírito de Rancor" pode causar dor nas costas. O "espírito de adultério" pode levar ao alcoolismo e à mitomania. A segunda é uma limitação imposta pelo demônio, dado que, por sua natureza ativa e inteligente, estrategicamente, mantém-se sorrateiro. A falsa aparência assumida intencionalmente o deixa à vontade para agir. A terceira é que a qualidade da ação do demônio importa mais do que o seu nome verdadeiro. Há, assim, um demônio que é responsável por investir na luxúria.
} 


\section{perifèria}

Número 19 (1), Juny 2014

revistes.uab.cat/periferia

\section{2. "Libertação", e não "exorcismo": a questão da "abertura"}

Poderia estudar o "exorcismo", porém, como afirmara o padre João, em uma "Missa de Cura e Libertação", na cidade de Ourinhos/SP: "O exorcismo é uma benção do padre concedida a uma pessoa por meio da aprovação do Bispo. A libertação é um carisma da comunidade para a comunidade", não uma comunidade estritamente humana, mas de vínculos constituídos entre seres com naturezas distintas. Um caso de "possessão" é excepcional, uma situação quase mortal, pois ser tomado por um demônio tem a ver com a desabitação de si por Deus: A "libertação (...) evita a necessidade de uma longa investigação psiquiátrica e da longa aprovação eclesiástica que precede o exorcismo" (Csordas 1994: 195).

A importância atribuída à "libertação", a pesquisa indica, é empírica em relação ao "exorcismo". Digo empírica porque a "libertação" conceitualmente "junta as peças do quebra-cabeça" (Bateson 2006: 306) de maneira mais extensiva em termos etnográficos, ao passo que o "exorcismo" teria o efeito contrário. O aprendizado da "libertação" tem a ver com estar atento àquilo que importa para os nativos: "Deixar Deus trabalhar", mas não há como conter essa laboriosidade. A "abertura" não é uma "brecha". Nesta o demônio age; naquela, deve-se "estar aberto para que Jesus faça algo". Os dois ocupam a posição de possíveis outros, embora atuem de maneira distinta: o demônio, indiscriminadamente; Deus, apenas quando a "pessoa quer", embora este "querer seja algo do coração, que esquenta, trepida, acelera". O coração é um órgão da vontade, onde, também, habita o "Espírito Santo".

A disjunção é sugestiva para a argumentação. Permite vislumbrar outra. A inimizade cosmológica, certa vez disse-me uma nativa, no centro da cidade de São Paulo/SP, "não permite que Jesus compactue com nenhum espírito do mal. Se a pessoa fica diante dele na Igreja e está com um espírito [maligno], ele [o demônio] tem que sair". O verbo sair não se restringe binariamente ao verbo entrar, isto é, sair não corresponde, imediatamente, à distinção entre interior e exterior, mas "sair de perto, parar de ficar ali em volta". Uma "manifestação", ela continua, pode acontecer porque as "misturas não se completam", as pessoas vão a "vários lugares" e depois "vêm para a Igreja". Ocorre, então, aquela "gritaria" porque 


\section{perifèria}

Número 19 (1), Juny 2014

revistes.uab.cat/periferia

"Jesus passa com vários anjos, e aquilo que tá ali fazendo mal para a pessoa não aguenta, manifesta de algum jeito". As misturas são interrompidas, cortadas, no momento que ocorre esse "choque" ou "combate", dois substantivos centrais na teoria nativa. A incompatibilidade é proveniente, entre outras coisas, da "contaminação", que pode acontecer por meio de um objeto material, de um alimento, de uma pessoa. A "renúncia liberta da contaminação", não obstante haja prevenções eficazes que permitem manter o "Inimigo afastado", segundo Clara.

A "manifestação", todavia, não é o fim último da "libertação", mas uma "absorção momentânea" (Veyne 1996: 251), o "um pouco" (Veyne 1996: 259-265). A "salvação", em geral, é a causa final e torna necessária a "renovação [diária] do preenchimento" pelo bem (Sales 2003: 76). A teoria nativa não produz um chavão acerca da "libertação", pois a "batalha" pode acontecer silenciosamente no "repouso no espírito", na genuflexão, nas "lágrimas", "olhos", "confissão", "comunhão", "perdão", "louvor", pela "boca", "ouvidos" etc..

\section{3. "Libertação" e "precaução"}

As inúmeras situações propícias para efetuar a "libertação", conforme delineado no fim do último tópico, alcançam as relações mais corriqueiras da vida nativa. Não me esqueço do constrangimento que passei no Ginásio do Ibirapuera, ao ajudar Maria, uma missionária solteira. Ela me ofereceu um biscoito, que aceitei. Ao devolver o pacote, ela traçou o sinal da cruz em si própria. Aquilo me perturbou. Nesse mesmo dia, vi outro nativo fazer o mesmo, tão logo the ofereceram um bombom. Não me contive e perguntei do que se tratava: "Para descontaminar", o mesmo que evitar que se "abra uma brecha", dois termos nativos conexos. Naquele evento, guloseimas podem estar "consagradas"20. A pequena "precaução" adere-se a inúmeras que são feitas para impedir o começo de um "ataque do Inimigo".

20 O adjetivo "consagrado" é uma estenografia nativa para inúmeros artefatos e pessoas que são dotados alguma agência maléfica ou benéfica. "Consagra-se" uma pessoa ao demônio. "Consagra-se" 


\section{perifèria}

Número 19 (1), Juny 2014

revistes.uab.cat/periferia

No trânsito, um movimento brusco de outro motorista pode ter como resposta uma jaculatória: "Passa na frente Maria". Todas as vezes que se sai de casa, a pé ou de carro, ora-se o "Pequeno Exorcismo de São Leão XIII", reza-se o rosário individualmente, com os familiares e para alguém ausente. Quando ocorre um desentendimento doméstico ou no trabalho, canta-se, mesmo que silenciosamente, um "louvor". Ora-se, sem "rancor", por alguém, pois do contrário a prece não tem efeito. Pede-se "perdão" a alguém mesmo que não haja motivo aparente para tal. Se ocorrer um pesadelo, reza-se um "Pai Nosso" ou se lê um salmo. Repete-se, com frequência, nos louvores, que a divindade, na "Consagração à Nossa Senhora", torne-se a proprietária do fiel, dos seus "ouvidos", "boca", "olhos", do "pensar", do "falar" etc.. Tornar-se "precaucionado" é um elemento recorrente e habitual (Veyne 1996) da "libertação".

No Retiro de Carnaval, da Missão Eucarística Círculo do Pão, já no ano de 2014, reencontrei-me com Paulo, que sentia dores do corpo e dormência toda vez que ficava na presença do ostensório com Jesus Sacramentado. Poucos meses antes, ele me contara que o abatimento era uma decorrência de sua passagem por outras religiões, tais como o Candomblé, a Umbanda e o Espiritismo. Paulo não tem dificuldade em salientar que

"o cara que não vive, que não está na unção, vivendo as coisas de Deus, o seu corpo não vai estar imune às coisas de lá. Pode ter certeza. Se você não vive as coisas de Deus, não está em comunhão, o seu corpo tá aberto para Ele [o demônio] tumultuar. De alguma forma, você vai sentir. Isso, aí, eu vi bem claro quando larguei as coisas".

Por esse motivo, ele se refugiava quando Jesus estava presente no ostensório. No Retiro sobredito, Paulo ressalta que o estreitamento da sua relação com a divindade

uma pessoa a Deus. "Consagra-se" o pão e vinho na Eucaristia, assim como se "consagra" um "brigadeiro" para enfeitiçar alguém. Em muitas ocasiões, contudo, a pessoa não sabe que algo dado, ofertado, é "consagrado". Clara, após as orações na capela, vira que uma pessoa, presente no grupo, "estava muito contaminada porque procurara o espiritismo várias vezes. Outra foi contaminada porque aceitou um sorvete, daqueles de bola, que vem no copinho. Estava preparado [consagrado]". 


\section{perifèria}

Número 19 (1), Juny 2014

revistes.uab.cat/periferia

não é o fim, mas intensifica a inquietação do "Caçador", uma das alcunhas do demônio, que ataca principalmente aqueles que ficam mais próximos de Deus: "Quanto mais entrega Eu [o demônio] ver, mais caça vai ter".

Essas palavras de Paulo são ditas no momento em que parece mais confiante. Não demora que desfie o nível de "precaução" com o qual se refere às suas agonias: "Muitas das vezes, o que Ele [o demônio] faz para te confundir? Quando você acha que é a sua dor física, é ele que está cutucando". A questão é como diferenciar, o que não the passa despercebido:

"(...) eu tenho que distinguir com oração (...) Se você sabe que é uma coisa espiritual, se entregue em oração porque você vai sentir que o negócio vai embora. Se partir, você sabe que é espiritual. Quando você sabe que é físico, é quando ela persiste em você (...) Hoje, de manhã, eu estava passando mal porque eu não tinha me alimentado. Eu comi o pão (...) Não me fez bem. Estava até com tontura (...) Eu fui na padaria, fiz [pedi] um suco de morango com leite e comi duas coxinhas. Na hora, passou. Eu poderia achar que era espiritual, mas, não, era físico. Eu não tinha me alimentado bem e era realmente isso (...) Às vezes, não é. Às vezes, estou alimentado bem, e Ele vem e ataca".

A "libertação" acontece continuamente, pois reanima a intimidade com a divindade cristã. A terapêutica nativa parece exibir aqui sua forma mais rotineira. Isso se daria naquela "abertura" para que Deus "trabalhe". A salubridade espiritual não procede, na maioria das vezes, de uma ocasião especial, do que se chama na literatura antropológica, classicamente, da performance de um ritual (Turner 1974), mas do desenvolvimento de "habilidades"21" (Ingold 2000) "precaucionais" aprendidas por meio do envolvimento contínuo com o mundo.

\footnotetext{
${ }^{21}$ Os conceitos de embodiment (1990) e de enskilment (Ingold 1993, 2000) são distintos. O primeiro opera, exclusivamente, em um meio ambiente cultural, enquanto o segundo abrange os constituintes humanos e não-humanos do meio ambiente (sobre a discordância de Ingold quanto ao embodiment, ver Ingold 2000: pp. 170-171).
} 


\section{perifèria}

Número 19 (1), Juny 2014

revistes.uab.cat/periferia

\section{4. "Libertação" e "Verdade"}

As "precauções" são postas em movimento através do relacionamento com a divindade. Não se deve negligenciar, portanto, aquilo que aparenta ser um dos problemas centrais da "libertação", da "cura espiritual". Ouve-se com frequência no campo que "a Verdade é uma pessoa"22 e que a "Verdade liberta. Ypuan, isso é óbvio para quem crê"23. A pessoa é o próprio Jesus Cristo, o "Cordeiro imolado", consumido diariamente na missa. Conferir alguma atenção aos dois enunciados enreda-nos em proposições que não são redutíveis à forma proposicional corriqueira, à norma de coerência. Exagero intencionalmente a diferença. É preciso assinalar que não são assimiláveis a não-contradição ${ }^{24}$.

Ao decompor apenas o primeiro enunciado predicativo, devido à presença do copulativo "ser", flexionado como "é", deparamo-nos com a junção, desde sempre contra-intuitiva, em termos representacionais (cognitivistas ${ }^{25}$ ), porque não coloca alguma conformidade entre sujeito e predicado. Em outras palavras, coloca a

\footnotetext{
22 O Evangelho de João é acionado de forma visceral: "Eu sou o caminho, e a verdade e a vida; ninguém vem ao Pai, senão por mim" (João, 14, 6). Em todo caso, as considerações sobre a Bíblia Sagrada podem ser exibidas de maneira diferencial, nem sempre tão intensamente vida cotidiana (Bonfim 2012).

${ }^{23}$ A crença não é um conceito do antropólogo, tampouco é uma razão de segunda classe, desqualificável (Latour, 2004), mas sim "inalcançável pela razão", conforme a teoria nativa.

${ }^{24}$ Enfim, não é articulável por meio do "princípio da identidade" porque reúne juízos díspares que estão diluídos nos enunciados nativos: "Jesus é livre na cruz"; "Ser livre é ser obediente"; "O mal é uma pessoa" etc..

25 Pascal Boyer entende que os conceitos religiosos transgridem as determinações do conhecimento intuitivo, sendo, então, contra-intutivos. Opõem-se a expectativas intuitivas desenvolvidas desde a infância - tais como a estabilidade das distinções entre plantas, animais e pessoas - porque misturam as qualidades inerentes a cada um desses seres: espíritos, então, podem ser materializados, os objetos materiais espiritualizados, os animais podem comportar-se como pessoas etc. (Boyer 2001: 57-
} 60). 


\section{perifèria}

Número 19 (1), Juny 2014

\section{revistes.uab.cat/periferia}

pessoa como atribuição da Verdade. Dizer que se "crê", ou não, é um truísmo que chega a ofender os nativos. A "Verdade" é uma verdade necessária, em lugar de uma verdade contingente. A primeira não pode ser diferente do que é, qual seja, não depende da nossa vontade. A segunda pode ser diferente do que é (Holbraad 2003). A etnografia acirrou uma questão que não esperava confrontar. A "libertação" seria, entre os missionários, um "encontro pessoal com a Verdade", os "passos no caminho da Verdade".

O ceticismo do antropólogo embota as práticas descritivas dos nativos (Holbraad 2003), o que as torna intimidantes quando o par verdade/mentira encontra-se em seres que não são humanos: Deus, Jesus Cristo, o Espírito Santo, os anjos, os Santos, o Diabo, os demônios etc. ${ }^{26}$. A questão não pode ser neutralizada por meio de uma argumentação moral, racionalizadora e ética (Mariz 1997). Tentaremos nos afastar dela. O conceito nativo de verdade seria irredutível à razão, enquanto uma pretensão de "explicar aquilo que é inexplicável" ou "infinito, o que não foi, o que não será, mas o que é", tal como é repetido pelo padre João. A "libertação" diz algo sobre conceitos, "(...) descrições de processos de conhecimento" (Bateson 2006: 306).

A "Verdade" aparece com um aspecto relacional, já que se defronta continuamente com a "mentira". Carlos Roberto F. Nogueira, não por acaso, recorda que o "Livro de Jó" "(...) coloca o grande problema do mal e da dúvida" (Nogueira 1987: 16). A "dúvida" e a "desconfiança" são estados aflitivos que os nativos narram com

\footnotetext{
${ }^{26}$ No trabalho de campo, a referência ao demônio não se circunscreve à imoralidade, mas a toma como aspecto secundário. A matriz é a disputa, ao redor da humanidade, que se desenrola entre os dois seres. Lembro-me que a primeira pregação que ouvi no Santíssima Trindade tinha o seguinte tema: "A Verdade que liberta", sendo iniciada por Dora, uma nativa de outra Comunidade, a partir do Evangelho de João:"conhecereis a verdade, e a verdade vos livrará (...) Em verdade, em verdade vos digo: todo homem que se entre ao pecado é seu escravo. Ora o escravo não fica em casa para sempre, mas o filho sim, fica para sempre. Se, portanto, o Filho vos libertar, sereis verdadeiramente livres (...) Vós tendes como pai o demônio e quereis fazer os desejos de vosso pai. Ele foi homicida desde o princípio e não permaneceu na verdade, porque a verdade não está nele. Quando diz a mentira, fala do que Ihe é próprio, porque é mentiroso e pai da mentira" (João, 8, 32, 34-36, 44).
} 


\section{perifèria}

Número 19 (1), Juny 2014

revistes.uab.cat/periferia

frequência quer quando são "atormentados" por algo na família, no trabalho, nas relações sentimentais, quer quando são vítimas de alguma "fatalidade". O início e a persistência de uma "atribulação" são ocasiões privilegiadas para que o nativo "questione" Deus. O desafio é "confiar na Verdade em meio à dor" 27.

A "queixa" e o "murmúrio" são ocasiões usuais para a ação demoníaca. Deus se torna o "culpado" pelo infortúnio. Abrem-se "brechas" para o "ressentimento" e para o "afastamento": "O que o encardido quer é que as pessoas sintam raiva de Deus [da "Verdade"]" e das outras. A "raiva" é uma "cilada do encardido: Ele ataca onde não há o perdão", lembra Clara. O distanciamento, nesse caso, é da ordem do "caminho" que se trilha. A querela Deus e o Diabo criaria uma multiplicação inevitável dos "caminhos" que alguém seguiria.

\section{5. "Libertação", "caminhada" e "cativeiro"}

Além da "Verdade" e da "precaução", há, por assim dizer, outro aspecto da "libertação": a "caminhada", uma noção cristã que vincula um deslocamento que se propaga nos atos de "seguir", de "dar um passo", de "carregar a sua cruz", "encontrar", "retornar" etc.. "Caminhar" precipita a necessidade de escapar do "cativeiro".

Se a "libertação" tem uma relação intensa com o "caminhar", as maneiras derivadas dela requerem uma "educação". A "Verdade", entre os nativos, é um ser com quem se "caminha" pelas ruas do centro de São Paulo/SP, durante a procissão de Corpus Christi, que "caminha pela nave da igreja", que se "segue", do qual se "alimenta", de quem se é "amigo" etc.. Daí a importância teórica atribuída a um

\footnotetext{
${ }^{27}$ Não é demasiado recordar que Otávio Velho (2007) atentara que, na "travessia do deserto", o povo se mostrava ressentido e lembrava "(...) do peixe que comíamos no Egito, dos pepinos, dos melões, das verduras, das cebolas e dos alhos. Agora estamos definhando. Privados de tudo; nossos olhos nada vêem senão este maná!" (Número, 11, 5-6 apud Velho: 109, n. 4).
} 


\section{perifèria}

Número 19 (1), Juny 2014

revistes.uab.cat/periferia

modo de conhecimento, no qual as peças são juntadas de forma que se "precaucione" contra o "cativeiro" e a "escravidão". As "ciladas" demônio impedem a existência de coisas que nada fazem (Latour 2001) ${ }^{28}$. A "aposta na imanência" dos objetos sublinha a importância que as "formas materiais" assumem a ponto de fazerem divindades e espíritos malignos circularem pelo mundo (Robbins 2011: 24). O aspecto sensorial da verdade põem em relação pensamentos, artefatos materiais, coincidências, pessoas, imagens, seres espirituais etc.. Todos podem produzir efeitos uns sobre os outros etc..

Tornar-se "oprimido pelo demônio", nas especulações nativas, é ceder à "tentação". Ocorre um desgarre e se é capturado. Passa-se da condição de "ovelha" para a condição de "escravo"29. Afasta-se do "caminho". O apresamento se dá pela "sedução", pela cativação. Um aspecto fundamental acerca do demônio é o reconhecimento da sua "astúcia", da sua habilidade, para conhecer a "fraqueza" da pessoa. Ele age naquilo que pode abrir uma "brecha" no cativado.

Uma das questões fundamentais da "libertação" e da "captura pelo demônio" é que as duas são ordem do caminhar, uma coisa geral da vida: do que se faz com os pés, com ouvidos, com a boca, com os olhos, com as mãos, com o nariz. Um nativo, em uma animada conversa na Casa Masculina, fez a seguinte exposição: "Eu gosto de tênis e vejo tênis bonitos todos os dias. O demônio sabe que gosto do tênis. Ele vai me fazer ver os tênis. Posso ver, mas se não consigo parar de pensar, ele começa a me atacar. Aí, eu posso fazer de tudo para ter aquilo". O demônio, por conseguinte, ele acrescenta, sempre se apresenta de uma "forma sedutora", pois se mostrasse como "Ele é, de verdade, ninguém ia se aproximar Dele".

\footnotetext{
28 Para o leitor mais atento, a juntura de Ingold e Latour pode parecer forçosa e descuidada. Ingold (2007, 2008), apesar da sua crítica à "teoria do ator-rede" (Jones, 2002), chega a sublinhar que ambos estão seguindo questões que sugerem mais aproximações do que diferenças radicais, as quais não impediriam de colocá-los em uma mesma composição.

${ }^{29}$ A ação maligna possui uma sucessão específica para "escravizar": "seduz", ou "cativa", "aprisiona", ou "escraviza" e, por fim, "destrói" a pessoa.
} 


\section{perifèria}

Número 19 (1), Juny 2014

revistes.uab.cat/periferia

Otávio Velho destacou que as tentativas dos pesquisadores para "descobrir", no caso do campesinato, "o que é, afinal, cativeiro" ordenaram uma cesura pela qual "se percebiam os informantes vivendo com extremado realismo, ao passo que os analistas, por sua vez, buscavam uma chave analógica explicativa que permitisse sua tradução" (Velho 2007: 105). A explicação, por conseguinte, suprimiu um fenômeno que terminou por ser associado à "expropriação" e à "proletarização" na Amazônia Oriental (Velho, 2007: 105).

O "cativeiro", nas palavras de Velho, emanaria da escravidão histórica ocorrida no Brasil, porém haveria uma cosmologia que mobilizaria essa noção, através de uma "cultura bíblica" em um "sentido forte", atingindo um nível de atitudes profundas (Velho 2007: 106). Velho nota que, "(..) desde pelo menos o Êxodo, o deslocamento representa uma fuga ao cativeiro" (2007: 120). A "escravidão" consiste, entre os missionários, em não se "libertar daquilo que se vê e julga. Tornar-se escravo das coisas do mundo". o "cativeiro", a "escravidão", é um problema do mal que está presente nas relações nativas com o "caminho", a "fuga", as "pedras", os "espinhos", a "tortuosidade", a "queda", a "Cruz que deve ser carregada", a "peregrinação", o "tropeço", as "idas e vindas".

A vivificação da "Verdade" no ato de "caminhar" e a "precaução", enquanto se desloca, exigem, talvez, outra maneira de analisar a "libertação". Devemos considerar que "caminhar", "fugir do cativeiro", não se faz na ordem da excepcionalidade. O "envolvimento perceptivo" imediato é a forma que o demônio toma, onde ele se "revela-oculta". A pessoa aprende a "educar a atenção", "uma educação do sensorial" (Gibson apud Ingold 2000: 21-22) para as "Suas [do maligno] armadilhas". Quem "é de caminhada", "que já caminha há muito tempo", detecta os rastros sutis deixados pelo demônio no plano da "cotidianidade". A probabilidade de evitar o "cativeiro" aumenta e limita a "sobreinterpretação" do analista. 


\section{perifèria}

Número 19 (1), Juny 2014

revistes.uab.cat/periferia

\section{Bibliografia}

Alves, Paulo C. (2006). "A fenomenologia e as abordagens sistêmicas nos estudos sócio-antropológicos da doença: breve revisão crítica". Cadernos de Saúde Pública, vol.22, no. 8, pp. 1547-1554.

Asad, Talal (1993). "Towards a genealogy of the concept of ritual". In: Asad, Talal Genealogies of Religion: Discipline and Reasons of Power in Christianity and Islam. Baltimore, MD: Johns Hopkins University Press, pp. 55-82.

Bateson, Gregory (2006) "Epílogo de 1958". In: Bateson, Gregory. Naven: um esboço dos problemas sugeridos por um retrato compósito, realizado a partir de três perspectivas, da cultura de uma tribo da Nova Guiné. São Paulo: Editora da Universidade de São Paulo, pp. 305-323.

Berger, Peter \& Luckmann, Thomas (1973). A Construção social da realidade: tratado de sociologia do conhecimento. Petrópolis: Vozes.

Bialecki, Jon (2011). "Quiet deliverances". In: Lindhardt, Martin. Practicing The Faith: The Ritual Life of Pentecostal-Charismatic Christians. New York/Oxford: Berghan Books, pp. 249-276.

Bonfim, Evandro (2012). A Canção Nova: Circulação de dons, mensagens e pessoas espirituais em uma comunidade carismática. Tese de Doutorado em Antropologia Social. Universidade Federal do Rio de Janeiro, Museu Nacional, Rio de Janeiro.

Boyer, Pascal (2001). "Cultural inheritance tracks and cognitive predispositions: the example of religious concepts". In: Whitehouse, Harvey (ed.). The debated mind: evolutionary psychology versus ethnography. Oxford/New York: Berg, pp. 57-89.

Csordas, Thomas J. (1990). "Embodiment as a paradigm for anthropology". In: Ethos, vol. 18, no. 1, March, pp. 5-47.

-(1994). The sacred self: a cultural phenomenology of charismatic healing. Berkeley: University of California Press.

-(2002). "Somatic modes of attention". Body/meaning/healing. New York: Palgrave Macmillan, pp. 241-259.

-(2004) "Asymptote of the ineffable: embodiment, alterity, and the theory of religion". In: Current Anthropology, vol. 45, no. 2, pp. 163-185

Douglas, Mary (1970). "The two bodies". In: Douglas, Mary. Natural symbols: explorations in cosmology. London: Barrie \& Rockliff: The Cresset Press, pp. 65-81. 


\section{perifèria}

Número 19 (1), Juny 2014

revistes.uab.cat/periferia

Durkheim, Émile (1996). As formas elementares da vida religiosa: o sistema totêmico na Austrália. São Paulo: Martins Fontes, 1996.

Evans-Pritchard, Edward E. (2005). Bruxaria, Oráculos e Magia entre os Azande. Rio de Janeiro, Zahar.

Favret-Saada, Jeanne (1989). "Unbewitching as Therapy". American Ethnologist, 16 (1), pp. 40-56.

-"Être Affecté" (1990). Gradhiva. Revue d'Histoire et d'Archives de I'Anthropologie, $\mathrm{n}^{\circ} .8,3$, pp. 3-9.

Frankenberg, Ronald (1980). "Medical Anthropology and Development: A Theoretical Perspective". Social Science and Medicine, pp. 197-207.

Good, Byron J. (2012). "Phenomenology, Psychoanalysis, and Subjectivity in Java". Ethos, vol. 40(1), pp. 24-36.

Holbraad, Martin (2003). Estimando a Necessidade: os oráculos de Ifá e a verdade em Havana. Mana, 9 (2), pp. 39-77.

Ingold, Tim (2000). "Culture, nature, environment: steps to an ecology of life". In: Ingold, Tim. The perception of the environment: essays in livelihood, dwelling and skill. London: Routledge, pp.13-26.

-(2001). "From transmission of representantions to the education of attention". In: Whitehouse, Harvey (ed.). The debated mind: evolutionary psychology versus ethnography. Oxford/New York: Berg, 2001, pp. 113-153.

-(2005). "Jornada ao longo de um caminho de vida - mapas, descobridor-caminho e navegação. Religião e Sociedade, 25 (1), pp. 76-110.

-(2007). "Up, across and along". In: Ingold, Tim. Lines: a brief history. London: Routledge, pp. 72-103.

-(2008). "Bindings against boundaries: entanglements of life in an open world", Environment and Planning A, 40 (8), pp. 1796-1810.

Jones, Andrew (2002). "From the perception of archaeology to the anthropology of perception: an interview with Tim Ingold". Journal of Social Archaeology, vol. 3 (1), pp. 5-22.

Katz, Jack \& Csordas, Thomas J. (2003). "Phenomenological ethnography in sociology and anthropology". In: Ethnography, 4 (3), 2003, pp. 275-288.

Kleinman, Arthur (1978). "Concepts and a Model for the Comparison of Medical Systems as Cultural Systems". Social Science and Medicine, 12, pp. 85-93. 


\section{perifèria}

Número 19 (1), Juny 2014

revistes.uab.cat/periferia

Leiban, Richard W. (1997). "The Field of Medical Anthropology". In: Landy, David (ed..). Culture, Medicin and Disease. New York: MacMillan, pp. 13-31.

Latour, Bruno (2001). A esperança de Pandora: ensaios sobre a realidade dos estudos científicos. Bauru, SP: EDUSC.

-(2004). "'Não congelarás a imagem", ou: como não desentender o debate ciênciareligião". Mana, 10 (2), pp. 349-375.

Langdon, Esther J.. (1994). Langdon, "Breve Histórico da Antropologia de Saúde" In A Negociação do Oculto: Xamanismo, Família e Medicina entre os Siona no Contexto Pluri-Étnico. Trabalho apresentado para o Concurso de Professor Titular na UFSC.

Langdon. Esther J. \& Follér, Maj-Lis (2012). "Anthropology of Health in Brazil: A Border Discourse". Medical Anthropology: Cross-Cultural Studies in Health and IIIness, 31 (1), pp. 4-28.

Lévi-Strauss, Claude (1967). Antropologia Estrutural. Rio de Janeiro: Tempo Brasileiro.

Mariz, Cecília L. (1997). "O demônio e os pentecostais no Brasil". In: Birman, Patrícia; Novaes, Regina \& Crespo, Samira (orgs.). O mal à brasileira. Rio de Janeiro: EdUERJ, pp. 45-61.

Montero, Paula (1985). Da doença à desordem: a cura mágica na Umbanda. Rio de Janeiro: Graal.

Nogueira, Carlos R. F. (1987). O Diabo no Imaginário Cristão. São Paulo: Editora Ática, 1987.

Robbins, Joel (2011). "Transcendência e Antropologia do Cristianismo: Linguagem, mudança e individualismo". Religião e Sociedade, 31(1), pp. 11-31.

Sahlins, Marshal (2004). "A tristeza da doçura, ou a antropologia nativa da cosmologia ocidental". In: Sahlins, Marshal. Cultura na prática. Rio de Janeiro: Editora da UFRJ.

Sales, Lílian (2003). "Ou quente, ou frio, senão vomitar-te-ei": um estudo das práticas rituais da Renovação Carismática Católica. Dissertação de Mestrado. São Paulo: FFLCH/USP.

Turner, Victor W. (1974). O processo ritual: Estrutura e Anti-Estrutura. Petrópolis, RJ: Ed. Vozes. 


\section{perifèria}

Número 19 (1), Juny 2014

revistes.uab.cat/periferia

Velho, Otávio (2001). "De Bateson a Ingold: Passos na Constituição de um Paradigma Ecológico". Mana, 11 (1), pp. 297-310.

-(2007). Mais Realistas do que o Rei: Ocidentalismo, Religião e Modernidades Alternativas. Rio de Janeiro: Topbooks, 2007.

Veyne, Paul (1996). "L'Interpretation et L'Interprète. A propos des Choses de La Religion". Enquetê, 3, pp. 241-272.

\section{Documentos:}

Bíblia Sagrada Ave Maria: edição de estudos (2011). São Paulo: Editora Ave-Maria, $1^{\circ}$ Edição. 